\title{
On the border of deep spirituality and psychosis... A case study
}

\author{
Na granicy głębokiej duchowości i psychozy... \\ Studium przypadku
}

\section{Ewelina Dziwota ${ }_{\mathrm{ABDEF}}$, Diana Żmuda ${ }_{\mathrm{BDE}}$, Rafał Dubiel ${ }^{1}{ }_{\mathrm{BDE}}$, Kamila Dziwota ${ }^{2}{ }_{\mathrm{DF}}$, Renata Markiewicz ${ }^{3} \mathrm{D}$, Marta Makara-Studzińska ${ }^{4} \mathrm{D}$, Marcin Olajossy ${ }^{1} \mathrm{DE}$}

${ }_{1} 2^{\text {nd }}$ Department of Psychiatry and Psychiatric Rehabilitation Medical University of Lublin, Poland

2 Department of Psychotherapy Jagiellonian University Collegium Medicum, Poland

${ }^{3}$ Department of Psychiatric Nursing, Medical University of Lublin, Poland

${ }^{4}$ Department of Applied Psychology, Medical University of Lublin, Poland

\begin{abstract}
This article is a case study of a 28-year-old patient diagnosed with F23. The report is preceded by an extensive literature review describing the situation of the mentally ill, in which psychiatry intermingles with spirituality and the sacrum.

The aim of the study was to investigate the relationship between religion/spirituality and schizophrenia as well as to draw attention to the complex problem of differential diagnosis of religious and spiritual problems. When is psychiatric treatment enough and when is intervention of a priest really essential?

The authors discuss the problem of mental disorders in connection with religion and spirituality in the clinical context. The article shows that it is very important that the processes of diagnosis and treatment take into account the patients' individual traits, beliefs, values and spirituality.
\end{abstract}

Keywords: spirituality, religion, mental disorders, schizophrenia

\section{Streszczenie}

Niniejszy artykuł jest studium przypadku 28-letniego pacjenta z rozpoznaniem F23, studium poprzedzonym rozległym przeglądem piśmiennictwa, obrazującym sytuację życiową człowieka chorego, na której tle psychiatria miesza się ze sferą duchową i sferą sacrum.

Celem autorów podejmujących ten temat było ukazanie wzajemnych relacji pomiędzy religią, duchowością i schizofrenią a także zwrócenie uwagi na złożone zagadnienie diagnozy różnicującej problemy religijne oraz duchowe. Kiedy wystarcza samo działanie specjalisty psychiatry a kiedy nieodzowna jest interwencja kapłana?

Autorzy ukazują zagadnienienie zaburzenia psychicznego w powiązaniu z religijnością i duchowością w kontekście klinicznym, niezwykle istotny wydaje się bowiem zarówno proces diagnozowania jak i leczenia poszczególnych jednostek, uwzględniając ich cechy, światopogląd oraz system wartości i aspekty duchowe.

Słowa kluczowe: duchowość, religijność, zaburzenia psychiczne, schizofrenia

\section{Introduction}

Typical schizophrenia treatment is based on the biopsychosocial model, which means it involves prescription of antipsychotic drugs and psychological interventions for patients and their families. This model the disease, however, fails to take into account the patient's religious beliefs. Yet, both religion and spirituality exert strong influence on the lives of people suffering from schizophrenia.

It is worth distinguishing a psychotic state from the so-called "spiritual emergency". The latter is a traumatic experience in which individuals feel their sense of identity is fragmenting; they have the impression that the values they have cherished so far are no longer valid, that the solid ground beneath their personal reality is radically changing. Often, new realms of mystical and spiritual experience enter their lives abruptly and dramatically, generating fear and confusion. This is accompanied by anxiety, problems coping with everyday life, work and relationships, and preoccupation with one's own mental health [1]. In this context, psychiatry hugely intermingles with religion and spirituality.

\section{The metaphysics of the schizophrenic world according to Kępiński}

According to Antoni Kępiński, the world of internal experiences in case of patients suffering from 
schizophrenia is characterized by a specific type of metaphysics, in which ultimate things come to the fore; these things dominate the content of schizophrenic delusions making them different from non-schizophrenic delusions. The metaphysical world of a schizophrenic patient revolves around three main trends: ontological, eschatological and charismatic. The ontological trend is a turn towards the fantasy and magic of a world imbued with mysterious energies, the forces of good and evil, as well as waves penetrating human thoughts and behavior. The perception of a patient with schizophrenia is characterized by the fact that they see anything as filled with divine or satanic substance. This means, from their perspective anything can have an impact in the battle between good and evil or between beauty and ugliness. There are certain recurring motifs in schizophrenia, like the pretended character of the customary picture of the world, a conflict of opposing forces and the possibility of action per distance. In this context, there are no independent events. One event depends on another, with some mutual influence, with the patient being in the center of this dense structure of the world. The eschatological trend, in turn, is mainly related to issues like the end of the world, the ultimate purpose of man, etc. The image of the end of the world might be more or less apocalyptic - either it is limited to the patient's immediate family or encompasses the entire globe. In schizophrenia, the catastrophic mood reaches a climax, which is preceded by a state of apprehension - the world becomes very mysterious; the anxiety increases. The Charismatic trend, as understood by Kępiński, is associated with the fact that the patient, who is in the central position of the world, feels immortal, immaterial, almighty, as either God or Satan; the fate of the entire world depends on them. They are endowed with holiness, divinity, Satanism; they live their entire life under the sign of a gift (charisma) [2].

\section{Religious practices of schizophrenic patients}

Researchers have looked at religious practices among patients with schizophrenia. A study from Switzerland showed that about one third of schizophrenic patients were highly involved in a religious community. Another $10 \%$ of the patients surveyed in the same study were engaged in minority religious movements. According to another study conducted in the same country, nearly one-third of the patients were members of religious communities and another third believed that spirituality played a significant role in human life. Studies from other parts of the world devoted to religious practices of mentally ill patients suggest that such practices are common in Europe and North America. More than 91\% of the patients admitted to taking part in private religious or spiritual practices and $68 \%$ participated in religious activities. Some studies which have compared religious practices in both patients with schizophrenia and the general population suggest that religious involvement is higher among the patients, while other findings indicate that religious attendance is lower in schizophrenic patients [3].

\section{Psychopathology and religion in schizophrenia}

Among the various aspects of religion and spirituality, the influence of religion and spirituality on psychopathology seems to be one of the best explored areas of research. Janus, in his book Psychopatologia a religia [Psychopathology and Religion, in Polish] describes structural parallels between mental health and religion against the background of the difficult field of research on the border of psychology, psychiatry and religion. Religious elements in mental disorders can be identified in three forms: as belonging to the picture of the disease (explicitly expressed religious content or overtly religious behavior) or as utterances and pathological behavior influenced by religious culture, or as systems of behavior, thought and ideas manifested in mental disorders which have no direct source in religious culture, but can be considered as modalities of functioning consistent with religious standards. Janus says that, along with Jung's proposition the soul is inherently religious. Jung talked about the religious function of the soul, which he understood as the wholeness of the conscious and unconscious components of the psyche. The structure of the soul, manifesting itself in dreams, visions, and other elements of mental functioning, is consistent with universal religious images. Thus, broadly understood religiosity is a function of mental life as such. In one of the chapters of his monograph, Janus pays attention to the dimensions of schizophrenia such as messianism, splitting and coincidentia oppositorum. The image of an individual fantasizing that they are a prophet, a messiah or God Himself has grown into a symbol of madness. Delusions of grandeur and of being a messenger are very common among schizophrenic patients and fulfil the important functions of isolation and social attunement as part of the dynamics of the disturbed mind. Entering into normal interpersonal relationships is always associated with a collapse of the sense of grandeur. In turn, splitting is connected with dualism - the tendency to divide people into the good and the bad, wise and foolish or pretty and ugly, which is especially prominent in episodes of disorganized thinking. The emergence of polarity can also be observed in the way schizophrenic patients transform certain religious ideas. Polar splitting involves idealization, that is assigning a maximum positive or a maximum negative value to an object manifested as deification or demonization of that object. Patients use splitting constantly in both their individual and social lives [4]. 
Generally speaking, delusions and hallucinations of religious nature are further categorized into those associated with religious and supernatural motifs. Religious delusions and hallucinations are closely linked to certain religious motifs, such as prayer, sin, possession, or religious figures, such as God, Jesus, Satan, prophet. Supernatural delusions and hallucinations have more general mystic references to black magic, spirits, demons, being bewitched, mythical heroes, sorcery, or voodoo. Research conducted among in-patients with schizophrenia suggest that the prevalence of religious delusions and hallucinations differs from country to country, ranging from 6-63.3\%. For instance, studies which have compared religious delusions in different countries have shown that they are more common in Germany than in Japan [16].

Other research studies suggest that patients who experience religious delusions value religion as much as those without such delusions. Yet, patients who suffer from religious-themed delusions report receiving less support from religious communities. Studies which have looked at religion in the context of psychopathology suggest that Christians are more likely to have religious delusions, especially those related to guilt or sin, than patients who are followers of other religions such as Islam. Other studies have shown that Buddhists experience delusions with religious content less frequently than Christians and Protestants are more likely to have religious delusions compared to Catholics or people without any religious affiliation. Another study shows that Roman Catholics suffering from schizophrenia are more likely to have religious delusions of guilt, as compared to Protestants and Muslims. A cross-cultural study which has compared people of different ethnic backgrounds indicates that in the case of paranoid delusions, Christian patients more often report being persecuted by a supernatural being than do Muslim and Buddhist patients. Other study suggests that religious and supernatural themes are more common in delusions of patients from Korea than those of their Korean-Chinese and Chinese counterparts [3]. Greenberg and Brom investigated patients who were followers of Judaism and reported that in those subjects hallucinations occurred more frequently during the night, which was connected with the patients' beliefs that they were more susceptible to demonic powers and demons at night [5]. Peters et al., who compared patients who were followers of Hinduism (Hare-Krishnas), Christianity and New Religious Movements with non-religious groups, demonstrated that patients from New Religious Movements experienced religious delusions more often than the other two groups [6]. Another study suggested that, compared to patients from Saudi Arabia, patients from the UK were more likely to experience religion-related auditory hallucinations. There are some contradictory findings regarding the relationship between religiosity and the presence of religious delusions. Some studies suggest a higher prevalence of religious delusions and hallucinations in patients with higher religiosity and other studies suggesting a lack of correlation between these two factors. Regarding socio-demographic variables, reports suggest that the religious content of delusions is associated with the marital status and education of patients with schizophrenia. Only a few studies suggest a relationship between religious delusions and cognitive deficits. Religious delusions have an impact on help seeking, treatment and outcome. It has been demonstrated that individuals who have religious delusions need more time to establish service contact, take more medications, have overall higher symptom scores and poorer social functioning. Those with religious delusions and hallucinations look for magico-religious healing, are not satisfied with psychiatric treatment and are more likely not to comply with it. There is ample evidence that patients experiencing delusions involving religious themes have poor treatment outcomes. They are also more likely to indulge in violence and self-harm. Some authors suggest that religious delusions may affect patients' health belief models, and consequently lead to poor treatment adherence [3].

\section{The influence of religious personality}

Erikson claims that due to its orientation toward worldly and ultimate matters, religion, though susceptible to pathological distortions, is essential to the development of an integrated mature personality [7].

Many studies have evaluated the effects of religion on the severity of psychopathology and have come up with contradictory conclusions. While some authors suggest that religious activity and beliefs are more intense in people who present more severe symptoms of the disease, especially psychotic and general symptoms, other authors have reported that increased religious activity is associated with reduced severity of symptoms. Furthermore, data suggest that higher religiosity or piety is associated with the absence of first-rank symptoms [3]. At this point, it is worth considering what religious personality is. Pastoral psychology defines religious personality as a complex whole of thoughts, emotions and behaviors which gives direction and coherence to human life. Just like the human body, personality is made up of a number of structures and reflects the influences of nature (genes) and the religious environment. The concept of religious personality also encompasses the temporal aspect of human existence; understood in this way, it contains memories of the religious past, mental 
representations of the present and ideas and expectations regarding the future. Religious personality is characterized by a distinctive set of attitudes, i.e., direct attitude toward God/the sacred; attitude toward forms of communication about God/the sacred offered to an individual in the course of education and socialization; and attitude toward organized, individual and communal forms of worship of God/ the sacred. Religiosity is one of the properties which constitute the human person through his/her relation to transcendent values [8]. Allport, in his book The Individual and His Religion states that the development of religion within each individual is conditioned by their bodily needs, temperament, and mental capacity, their psychogenic interest in values, his/her pursuit of rational explanation, and his/her response to his/her culture. Allport elaborates on the notions of adolescent and mature religious sentiment, conscience and mental health. He explains what is at the heart of doubt and faith, assuming that mature religious sentiment is diversified, has a dynamic character, that despite its derivative nature, it engenders consistent morality, that it is versatile, holistic and heuristic [9].

Researchers show that religiosity in patients with schizophrenia is predictive of increased social integration, reduced risk of suicide attempt, reduced consumption of psychoactive agents, reduced smoking rates, better quality of life and a better prognosis. The conclusions regarding the relationship between religion and psychosocial adaptation are contradictory with a slight advantage of the notion that religiousness improves psychosocial adaptation. Religious support and spirituality foster social recovery and reduce relapse in some patients. In others, however, higher religiosity religiosity means an increased risk of a suicide attempt $[18,23]$.

A study which has examined the relationship between the level of religious activity and mental health in sub-groups of Catholics, Protestants and Jews has found that patients who do not get involved in religious practice have higher levels of mental disorders. A 1983 metaanalysis of 24 studies confirmed that religiosity was moderately but positively correlated with psychological outcome. The healing effect of religious involvement was related to factors such as suicide rate, addiction to drugs and alcohol, crime, marital satisfaction, and depression [7]. Religiosity affects people's susceptibility to illness, including mental illness because religiously mature people are characterized by good control of healthenhancing behaviors. In addition, such individuals enjoy social support and live in traditional religious relationships. As a result, they more often experience positive emotions and are generally healthier [10]. A 2009 issue of the Canadian Journal of Psychiatry contains a review of research on religion, spirituality and mental health written by Koening. This systematic study of mental health research conducted in medical, psychiatric, and other settings and encompassing many ethnic backgrounds (Caucasians, African Americans, Hispanic and Native Americans), different age groups (young, middle-aged and elderly) and different locations (the United States, Canada, Europe, and countries in the East), shows that religious involvement is associated with better coping with stress and lower suicidal tendencies, lower depression, anxiety, and substance buse [11].

\section{Religious coping}

Religious coping is the use of religious beliefs or behaviors to facilitate problem-solving with a view to prevent or alleviate the negative emotional consequences of distressing life circumstances. It is a multidimensional concept which refers to functionally-oriented expressions of religion in times of distress. The concept of religious coping has been refined and categorized as helpful and positive or harmful and negative or as having mixed implications. Strategies of positive religious coping include: purification, forgiveness, spiritual direction religious assistance, seeking support from the clergy, setting of certain moral boundaries. Negative religious coping strategies include spiritual discontent, demonic reappraisal, passive religious deferral, falling out of a social role, the reappraisal of supernatural forces and pleading for direct intercession. Religious coping strategies with mixed implications include religious rituals in response to crises, self-directing and deferral $[3,21]$.

Several studies have included cases describing schizophrenic patients and the role of religion in their dealing with stressful situations. These studies suggest that more than $80 \%$ of patients use religion to cope with their illness. Others report that in $45 \%$ of cases spirituality and religiousness helped the patients deal with their disease. Studies which have compared different disorders demonstrate that patients with a diagnosis of schizophrenia, bipolar disorder and schizoaffective disorder use "religious coping" on a long-term basis and see it as being more helpful in fighting the disease compared to patients with depressive disorder $[17,18]$.

Studies also indicate that religious coping affects other parameters. It turns out that religious coping in patients with schizophrenia is positively correlated with psychological and existential well-being. In the light of these reports, proper religious development corresponds with better well-being, better adjustment and lesser sense of loss associated with mental illness, whereas punishing God reappraisal and reappraisal of God's powers are associated, with a greater correlation, with poorer wellbeing and adjustment and greater personal loss caused by mental illness [3]. 
Positive religious coping is also predictive of a higher quality of life with regard to psychological health. By contrast, negative religious coping is associated with a lower quality of life and an increased level of distress measured on the Depression, Anxiety and Stress Scale. Longitudinal studies have shown that a stronger impact of religion on the patient's life and use of positive religious coping are predictive of a higher quality of life and better scores on the Clinical Global Impression scale $[17,22]$.

\section{The priest or the psychiatrist?}

Studies from around the world which have evaluated the explanatory models of disease held by patients with schizophrenia suggest that many patients have nonmedical explanations for their illness. Most of the nonmedical explanations across various analyses revolve around the influence of supernatural forces. Various explanations include being under the spell of a witch or a genie; esoteric, spiritual or mystical factors; family problems; inner problems of the self, economic difficulties, supernatural powers, ghosts, devils, being possessed by a demon, divine wrath, planetary/astrological influences, unsatisfied souls, evil deeds from the past. A study conducted in India reports that approximately $66-70 \%$ of patients have a non-biomedical explanatory model of their disease, while studies from other parts of the world indicate the presence of such explanatory models of schizophrenia in approximately $10 \%$ of patients. A cross-cultural study of Muslims from Arabia, patients from Jordan and Germany suggests that Jordanians are more likely to believe in esoteric factors affecting their illness and thus perceive it as being more dangerous. Other studies suggest that Caucasians mention biological causes more frequently than African-Caribbeans and Bangladeshis, who often point to social conditions as the cause of their disease. Data also suggest that non-medical explanatory models of schizophrenia affect insight and help-seeking and are associated with a worse clinical outcome [19].

A study from India shows that many patients seek treatment from healers who can get rid of the symptoms, which shows that native methods of healing are considered as being complementary to medical management of mental disorders. A survey conducted among in-patients of a mental hospital in Tamil Nadu, in Southern India showed that $58 \%$ of the psychotic patients had visited a religious healer before referring to a psychiatrist. In fact, studies suggest that seeking religious support is often the first step in the management of mental disorders, which is the consequence of patients holding culturally-rooted explanatory models of the disease. Research from other parts of the world suggests that patients with schizophrenia who are admitted for a long duration experience spiritual suffering. Studies devoted specifically to religiosity suggest that higher religiosity is associated with a lower preference for psychiatric treatment [20].

The role of priests in psychiatric treatment, whether or not they react maturely to the challenge and to what extent they are able to tell religious content in a mental illness from religious experience (natural or pathological) may crucially determine the patient's fate. Recent medical education curricula in psychiatry postulate that psychiatrists should have some knowledge about religion and recommend that that they should be sensitive to matters of religion and be able to talk with patients about their spiritual life and religious needs [7]. The domains of religion and health, especially mental health, should be linked in a way that would allow the psychotherapist and the priest, also an exorcist priest, to cooperate for the good of the patient. The more so that mental health in modern societies seriously falters: hard indicators such as the number of suicides, addictions, crime, post-stress disorders, and prevalence of depression are growing at a rapid pace. Some thirty percent of patients, especially psychiatric patients, experience spiritual problems. An analysis of studies on psychotic phenomena, especially those regarding subjective religious experiences, demonstrates that cooperation between a priest and a physician for the good of the patient is viewed as obvious and necessary [10].

\section{A clinical perspective}

Prusak, in his work "Diagnoza różnicująca problemy religijne bądź duchowe - możliwości ograniczenia kodu V 62.89 w DSM-5" [Differential diagnosis of religious and spiritual problems - the possibilities of restricting code $\mathrm{V}$ 62.89 in the DSM-5, in Polish] examines religion and spirituality in the clinical context - it turns out that psychological help is the most effective when it is adjusted to the traits of a specific person, their beliefs, values, spirituality and religiousness [12].

Category V 62.89 (Z 65.8) can be used when a clinician deals with a religious or spiritual problem. Examples include distressing experiences that involve the loss or questioning of faith, problems associated with conversion to a new faith or questioning of spiritual values, not necessarily related to an organized church or religious institution [13]. Until the publication of the DSM-IV, in its earlier versions, and in the ICD, religious and spiritual experiences had been perceived as the cause of psychopathology or as symptomatological expressions of psychopathology, while religion and spirituality were over-represented in the examples used to illustrate psychopathology. Psychiatrists and psychologists who developed the outline of code V 62.89 consider these anomalous experiences to be cases of "spiritual crises" or 
"spiritual emergencies", as discussed in the introduction to the present article $[12,14]$.

As this very review shows, elements of religion are ubiquitous in psychopathology. Religious content is often found in schizophrenia and the metaphysical themes of delusions described by Kępiński manifest themselves in three ways: ontological, eschatological and charismatic. In endogenous depression, a psychiatrist must deal with delusions of condemnation, guilt and punishment and an obsessive-compulsive disorder he/she has to alleviate the patient's obsessive religious thoughts. Psychiatrists have to switch their focus when they have to handle the patient's existential dilemmas or ideological crisis. In such cases, the psychiatrist is should be acting with great caution and stay sensitive to the patient's value hierarchy. The commonly postulated neutrality of the therapist not only requires them to be mindful and respectful of the patient's spiritual dimension, but also to suggest contacting a spiritual leader, like a theologian or a priest [7].

\section{Case report}

The patient was a 28 year-old male, single, childless, living with his aunt and uncle. The patient's parents had died from cancer when he was 8 and 10 years old. Both parents had probably suffered from paranoid schizophrenia. The parents parted soon after the patient's birth and he met his father only a few times in his life. The man had no siblings and was raised by his maternal grandparents. His grandmother died three years before this study was commenced and his grandfather died when the patient was 9 years old; the patient still considers his grandfather as his greatest authority. The patient did not know his grandparents from the side of the father.

He regularly attended school, had reasonably good marks, did not play truant, and never showed any discipline problems. He attained secondary education with the certificate of technician economist but never worked in the profession. He enrolled at a university, probably to avoid military service, but did not complete his studies. Since the age of 19 , he had been earning his living working at construction sites in Poland and Norway. He quit his job in November 2012, at the age of 26, when he felt a calling and decided to join a religious order. Even as a child he had been very religious, with religiosity hugely instilled in him by his grandmother. He very often prayed and went to church: "Mary was the most important figure in my life; I always asked her to intercede with God for help." In recent years, he went to church more often ("I had this need"); he traveled to holy places to pray; he went on a pilgrimage to Fatima. "I sensed God's help, I felt protected." In addition, the patient had dreams in which he saw various churches and the Mother of God calling people to prayer. In reaction to these dreams, the patient traveled around Poland looking for the churches from his dreams and then he prayed in them for the souls in the Purgatory. He described these dreams as "prophetic." The amount of time he devoted to religion clearly increased when his five-year relationship broke up. The patient had been planning a wedding, but the girl's parents had decided he was not the right candidate. "It's a good job I didn't get married; marriage would forestall my spiritual development."

He spent a year in a monastery, serving his novitiate until January 2014, when the prior ordered him to leave the monastery and consult a psychologist. Upon taking history, he was reluctant to describe his condition in that period but admitted to having had "unwanted, strange and blasphemous" thoughts. At that time, he claimed "he had been unable to tell good from evil." He had had a lot of thoughts in his head alternating with a fear of something bad, of Satan. "I had the impression that Satan was in me, I wondered whether I was possessed." "I did not hear any voices, I did not see any signs." "Satan wanted to destroy my soul; that was probably because I had prayed the Rosary many times, and Satan did not like it." The patient consulted a psychiatrist, but seeing no improvement, discontinued the prescribed medications after one and a half week. In February 2014, his aunt, worried about his condition, took him to Mental Health Hospital in Radecznica. . The patient agreed to hospitalization and spent two months in the ward. At that time, as he claimed, he was receiving medication on a regular basis. After discharge, he withdrew from taking medication (olanzapine) as it, as patient put it, "fuddled his brain" The patient did not feel he was mentally ill; explaining all the difficulties as punishment for his sins instead; he said he had no one to pray to because Jesus had left him. "I have forsaken God, and now I feel nothing when praying; I would do everything to make Him come back to me." "In church, I felt that God was speaking directly to me through the person of the priest, but those on a lower level of spirituality do not understand this."

As the patient's condition failed to improve, his aunt persuaded him to report to the Department of Psychiatry in Lublin. In the admission room, he refused to answer questions concerning his symptoms, denied having any somatic illnesses, addictions, allergies or head injuries. He had good orientation as to place, time and person, was calm and his behavior was appropriate to the circumstances. It was observed he had thought disturbances; he expressed delusional ideas but showed no signs of a personality disintegration. The patient refused to receive medical treatment. He claimed that his problems were only "a spiritual matter." There were no reasons to start the treatment, especially that the patient has not agreed for it. Due to that, he was discharged with a diagnosis of brief reactive psychosis (F23) and a recommendation of 
follow-up observation for suspected schizophrenic process. During hospitalization, the patient underwent an electroencephalographic examination (normal result), neuropsychological testing (result within the normal range), and psychological evaluation using MMPI-I (the result pointed to an attitude of dissimulation).

According to the information obtained from the doctor who treated the patient in the out-patient mental health clinic, the man felt good after discharge from the Department of Psychiatry. He did not exhibit any psychotic symptoms and asked the doctor for a health certificate, as he wanted to join the monastery again. Later on, he received the certificate.

\section{Discussion}

Even despite the relationship between religion and schizophrenia is so close, the spiritual aspect is often overlooked in mental health assessment, diagnosis, and treatment. The limited pool of available studies show that religion exerts influence over the expression of psychopathology, behaviors related to treatment seeking, and treatment outcome. Taking into account the importance of both religion and spirituality to many patients, the biopsychosocial model of schizophrenia should incorporate these factors in order to achieve a whole-person approach to treatment. Findings suggest that clinicians are rarely aware of the importance of religion to patients, even in cases when spirituality should be incorporated into treatment and patient care [15]. Hence, there is a strong need to make clinicians aware of the needs of patients suffering from schizophrenia and encourage them to evaluate the religious and spiritual aspects of their patients [3]. Religion sometimes intermingles with pathology. In fact, religious delusions are common among psychotic individuals. Yet, normal, healthy beliefs and religious practices play a stabilizing role and may reduce the overwhelming isolation, fear and loss of control experienced by psychotic patients. Clinicians should be aware of the beliefs, as well as both religious and spiritual involvement of their patients, appreciate their value, treat them as a resource which benefits healthy psychological and social functioning. They should also be able to recognize the situations where these functions are impaired. There is a need for some further investigation in this area, especially from a crosscultural perspective. More in-depth knowledge of the relationships between religion and various aspects of schizophrenia will lead to better treatment outcomes, as doctors will understand their patients better.

This case report illustrates the particular difficulty that psychiatrists might be facing while assessing psychopathology at the border of the cultural and religious areas. For a physician looking throught the lens of their own culture, the fact that the patient was raised in a deeply religious family might be tantamount to the diagnosis of a mental disorder. Various authors pay attention to the importance of taking an in-depth medical history of the patient and getting acquainted with the cultural and religious determinants of his/her behavior and words, i.e. so-called cultural aspects of diagnosis. Much research indicates that psychiatric and psychological assistance is most effective when it takes into account the specific beliefs, values, spirituality and religiosity of the patient $[24,25]$. Moreover, studies show that patients are less inclined to trust professionals and reveal their religious experiences [24] if they either feel or even suspect their negative attitude toward the spiritual life [26,27]. A good example is our own patient, who did not perceive his problem to be of a medical nature but rather a spiritual one. Therefore, he assumed that he would be misunderstood by the people around him. This is why he had refused to cooperate from the very beginning of hospitalization claiming that he could not be understood. Accordingly, he dissimulated and gave only brief descriptions of his religious experiences. This made the diagnostic process much more difficult.

In this particular case, apart from suffering from psychosis, the patient also showed an immature religious sentiment. He experienced religion in a child-like fashion, which was indicated by the fact that he had been counting his prayers (he prayed the Rosary five thousand times during a year).

According to statistical data [28], one third of university students have religious or spiritual problems that hugely affect their lives. In light of the above, obliviousness to the patient's religious and spiritual history is a serious negligence [29]. Research on the attitudes of clinicians toward patients' spirituality $[30,31]$ suggests that they usually judge patients' experiences by their own cultural standards, which means they may diagnose a non-psychotic patient as psychotic or "potentially psychotic", or the other way round. A short example for illustration only. A patient reports a peak experience, i.e a sense of delight, elation, illumination, or even ecstasy felt in a moment of self-actualization. Such peak experiences can occur in healthy people and have been described by Maslow as those that remain within the limits of a psychological norm [32] . However, when a physician only takes a cursory history and does a brief physical examination, he/she may overlook the fact that he/she is dealing with a different way of experiencing things and categorize the experience as psychopathological.

In the life of a patient, religious experiences may cooccur with psychopathology without affecting it, or affecting it through one of the three functions that religion can fulfil. These include:

1. The positive (salutogenic) function - religion helps patients to build relationships, encourages them to take an active attitude, and is a source of support, 
2. The pathoplastic function - spirituality becomes an expression of different forms of thinking and behavior; it provides refuge,

3. The pathogenic function - spirituality can act as a stressor by deepening the patient's weakness or leading to serious maladjustment. [33].

In the case reported in this paper, religion played a pathoplastic function; it served as a shelter, a way of coping with the disease, an explanation for it and a means through which to deny it. The patient regarded his problem not as a medical one but rather as a spiritual one. This led to mistrust of the medical staff (dissimulation, a sense of being misunderstood, failure to cooperate) and frustrated the diagnostic process. There was also another difficulty in the diagnostic process - the lack of standardized instruments allowing a physician to draw the line between deep spirituality and psychopathology.

centrum tej gęstej struktury swiata. Nurt eschatologiczny obejmuje z kolei sprawy końca świata, ostatecznego celu człowieka itp. Obraz końca świata może być mniej lub bardziej apokaliptyczny, może ograniczać się do najbliższej rodziny lub obejmować cały glob. W schizofrenii nastroje katastroficzne osiągają swoje apogeum - poprzedza je stan wypełnionego grozą oczekiwania, świat staje się badzo tajemniczy, narasta lęk. Nurt charyzmatyczny w pojmowaniu Kępińskiego wiąże się z tym, że chory stojący w centralnej pozycji świata czuje się nieśmiertelny, niematerialny, wszechmocny, czuje się bogiem lub szatanem, istotą, od której zależą losy całego wszechświata. Otrzymuje on świętość, boskość, satanizm, w znaku łaski (charisma) zamyka się całość jego życie [2]

\section{Praktyki religijne chorych na schizofrenię}

Prześledzono praktyki religijne wśród pacjentów chorych na schizofrenię. Badanie ze Szwajcarii wskazuje, że około jedna trzecia tych pacjentów to osoby wysoce zaangażowane w religijne wspólnoty. Inne 10\% pacjentów tego badania angażuje się $\mathrm{w}$ mniejszościowe ruchy religijne. Zgodnie $\mathrm{z}$ innym badaniem prowadzonym w Szwajcarii - blisko jedna trzecia pacjentów działa w religijnych wspólnotach a kolejna jedna trzecia sądzi, że duchowość odgrywa znaczącą rolę w życiu człowieka. Badania z innych regionów świata poświęcone praktykom religijnym pacjentów chorych psychicznie sugerują, że te są powszechne w Europie i Ameryce Północnej. Ponad 91\% pacjentów oddaje się prywatnym religijnym lub spirytualnym praktykom a $68 \%$ jest członkami publicznych służb czy działań religijnych. Niektóre badania, zestawiające praktyki religijne u pacjentów ze schizofrenią i w populacji ogólnej sugerują, że religijne zaangażowanie jest większe wśrod omawianych pacjentów, podczas gdy inne dane donoszą, że religijna frekwencja jest mniejsza u pacjentów ze schizofrenią [3].

\section{Psychopatologia i religia a schizofrenia}

Wśród różnych aspektów religii i duchowości, wpływ religii i duchowości na psychopatologię wydaje się być jednym z najbardziej eksplorowanych obszarów badań. Damian Janus w pracy pt. "Psychopatologia 
a religia" ukazuje strukturalne zbieżności pomiędzy zaburzeniami psychicznymi a religią, mając na uwadze trudne pole badań z pogranicza psychologii, psychiatrii i religii. Pierwiastki religijne w zaburzeniach psychicznych można zidentyfikować $\mathrm{w}$ trzech postaciach: jako należące do obrazu choroby, treści o tematyce religijnej wypowiadane expressis verbis lub jawne zachowania o takim charakterze, bądź jako wypowiedzi i patologiczne zachowania, mające swe uwarunkowania $\mathrm{w}$ oddziaływaniu kultury religijnej, lub też jako prezentowane $\mathrm{w}$ ramach zaburzeń psychicznych systemy zachowań, myśli i wyobrażeń, które nie mają bezpośredniego źródła w oddziaływaniu kultury religijnej, ale można je rozpatrywać jako modalności funkcjonowania zbieżne ze standardami ujawnianymi przez religie. Zgodnie z tezą Junga - pisze Janus - dusza jest z natury religijna. Jung mówił o funkcji religijnej duszy, która oznaczała całość świadomej jak i nieświadomej psychiki. Jej struktura ujawniająca się w snach, wizjach oraz w innych elementach funkcjonowania psychicznego - jest zgodna $\mathrm{z}$ uniwersalnymi obrazami religijnymi. Zatem szeroko rozumiana religijność stanowi funkcję życia psychicznego jako takiego. W jednym z rozdziałów swojej monografii Janus podkreśla wymiary schizofrenii takie jak mesjanizm, rozszczepienie i coincidentia oppositorum. Obraz człowieka rojacego sobie, że jest prorokiem, mesjaszem lub samym Bogiem urósł do rangi symbolu szaleństwa. Urojenia wielkościowe i posłannicze są nader częste $\mathrm{w}$ schizofrenii spełniając ważną funkcję izolacji i syntonii w ramach dynamiki zaburzonego umysłu. Wejście $w$ normalne relacje międzyludzkie zawsze związane jest z pewnym upadkiem poczucia wielkości. $\mathrm{Z}$ rozszczepieniem $\mathrm{z}$ kolei wiąże się dualizm - tendencja do dzielenia ludzi na dobrych i złych, głupich i mądrych czy ładnych i brzydkich, występująca niezwykle wyraźniew momencie schizofrenicznej dezorganizacji. Ten proces wyłaniania się biegunowości można obserwować także $\mathrm{w}$ przemianach pewnych wyobrażeń religijnych. Zjawisko biegunowego rozszczepiania jest związane $\mathrm{z}$ idealizacją, $\mathrm{w}$ sensie nadawania danemu przedmiotowi maksymalnej wartości pozytywnej lub negatywnej w postaci jego ubóstwienia czy demonizacji. Występuje ono stale na poziomie życia indywidualnego i społecznego [4].

Ogólnie rzecz biorąc, urojenia i halucynacje religijnej natury są dalej kategoryzowane jako te związane z religijnymi i nadprzyrodzonymi motywami. Urojenia religijne i halucynacje odnoszą się ściśle do pewnych religijnych tematów jak np. modlitwa, pacierz, grzech, opętanie czy postaci religijnych jak Bóg, Jezus, szatan, prorok. Urojenia nadprzyrodzoności oraz halucynacje mają bardziej ogólne mistyczne odniesienie do czarnej magii, duchów, demonów, bycia zaczarowanym, bohaterów mitycznych, czarnoksięstwa, voodoo. Badania prowadzone wśród pacjentów hospitalizowanych z rozpoznaniem schizofrenii sugerują, że występowanie urojeń religijnych i halucynacji różni się w poszczególnych krajach i wynosi od 6 - 63,3\%. Badania, które porównywały urojenia religijne $\mathrm{w}$ różnych krajach wskazują, że urojenia religijne są bardziej powszechne w Niemczech w porównaniu z Japonią [16].

Badania sugerują ponadto, że pacjenci doswiadczający urojeń religijnych wartościują religię $\mathrm{w}$ tak dużym stopniu jak ci bez tego typu urojeń, ale pacjenci prezentujący urojenia z kontekstem religijnym otrzymują mniej wsparcia płynącego ze wspólnot religijnych. Badania, które oceniały religię w kontekście psychopatologii sugerują, że chrześcijanie mają więcej urojeń religijnych, w szczególności urojeń winy czy grzechu, niż odpowiedni pacjenci będący wyznawcami innych religii jak np. islamu. Inne badania pokazały, że porównani do chrześcijan buddyści mają rzadziej urojenia związane $z$ tematyką religijną $i$ że protestanci doświadczają więcej urojeń religijnych niż katolicy i osoby bez religijnej przynależności. Inne badanie raportuje wyższą częstość urojeń religijnych winy u pacjentów ze schizofrenią - rzymskokatolików, zestawianych z protestantami i muzułmanami. Międzykulturowe badanie porównujące ludzi $\mathrm{z}$ różnym tłem etnicznym wskazuje, że w przypadku urojeń paranoidalnych pacjenci chrześcijańscy częściej relacjonują prześladowców będących istnieniem nadprzyrodzonym w porównaniu do pacjentów muzułmańskich i buddystów. Inne dane sugerują, że tematyka religii czy nadprzyrodzoności w urojeniach jest bardziej powszechna u pacjentów koreańskich niż koreańsko-chińskich czy chińskich [3]. Greenberg i Brom badali halucynacje pacjentów będących wyznawcami judaizmu i relacjonowali, że halucynacje występowały częściej w nocy, co było związane z wierzeniami pacjentów, że są wówczas bardziej podatni na diabelskie moce i demony [5]. Peters i współ. porównywali pacjentów należących do hinduizmu (wyznawcy Hare-Krishna), chrześcijaństwa i nowych ruchów religijnych z niereligijnymi grupami i wykazali, że pacjenci $\mathrm{z}$ nowych ruchów religijnych doświadczają częściej urojeń religijnych niż dwie pozostałe grupy [6]. Inne badanie sugeruje, że $\mathrm{w}$ porównaniu do pacjentów z Arabii Saudyjskiej pacjenci $\mathrm{z}$ Wielkiej Brytanii doświadczają o wiele częściej, opartych na motywach religijnych, halucynacji słuchowych. Odnoście związku pomiędzy religijnością a obecnością urojeń o treści religijnej i takowych omamów wnioski są sprzeczne z kilkoma badaniami sugerującymi wyższą częstość występowania urojeń religijnych i halucynacji u tych pacjentów $\mathrm{z}$ wyższym poziomem religijności, wiele $\mathrm{z}$ badań sugeruje brak korelacji między tymi dwoma czynnikami. Odnośnie zmiennych socjodemograficznych 
raporty sugerują, że religijna treść/zawartość urojeń jest związana ze stanem cywilnym oraz poziomem wykształcenia u pacjentów cierpiących na schizofrenię. Dość nieliczne badacze podają związek pomiędzy urojeniami religijnymi a deficytami poznawczymi. Urojenia religijne wpływają na szukanie pomocy, leczenie i wyniki. Zostało udowodnione, że osoby doświadczające urojeń religijnych potrzebują więcej czasu na nawiązanie kontaktu, przyjmują więcej leków, mają ogólnie więcej symptomów choroby i gorsze funkcjonowanie społeczne. $\mathrm{Ci}$ z religijnymi urojeniami, halucynacjami poszukują magiko-religijnych uzdrowień, nie są usatysfakcjonowani leczeniem psychiatrycznym i bardzo często nie przystają na nie. Są liczne dowody na to, że pacjenci doświadczający urojeń o treści religijnej mają słabe wyniki leczenia, częściej popadają w przemoc i samookaleczenia. Niektórzy autorzy sugerują, że urojenia religijne mogą wpływać na modele przekonań zdrowotnych oraz konsekwentnie prowadzić do ubożenia procesu leczenia [3].

\section{Wpływ osobowości religijnej}

Erikson twierdzi, że religijność, chociaż podatna na patologiczne wypaczenia, jednocześnie poprzez swoją orientację na sprawy doczesne i ostateczne, jest niezbędna do powstania zintegrowanej dojrzałej osobowości [7].

Wiele badań oceniało wpływ religii na ciężkość psychopatologii i okazuje się, że tutaj wnioski są sprzeczne. Niektórzy autorzy sugerują, że aktywność religijna i wierzenia są intensywniejsze, moc u osób, które doświadczają poważniejszych symptomów choroby, szczególnie objawów psychotycznych i ogólnych, podczas gdy inni autorzy donoszą, że rosnąca aktywnosć religijna jest związana $\mathrm{z}$ redukowaniem poziomu objawów choroby. Dane co więcej sugerują, że wyższa religijność czy też pobożność jest skojarzona z brakiem first-rank symptoms [3]. Warto rozważyć w tym miejscu czym jest osobowość religijna. W kontekście psychologii pastoralnej osobowość religijna to złożona całość myśli, emocji i zachowań, nadająca kierunek i spójność życiu człowieka. Tak samo jak ciało, osobowość składa się z szeregu struktur oraz odzwierciedla działanie natury (geny) oraz środowiska religijnego. Pojęcie osobowości religijnej obejmuje również temporalny aspekt funkcjonowania człowieka, osobowość tak pojmowana zawiera wspomnienia religijnej przeszłości, reprezentacje umysłowe teraźniejszości oraz wyobrażenia i oczekiwania co do przyszłości. W osobowości religijnej można wyodrębnić charakterystyczny zespół postaw tj.: bezpośrednie ustosunkowanie do Boga, sacrum; ustosunkowanie wobec form przekazu o Bogu, sacrum, które są oferowane człowiekowi w toku wychowania i socjalizacji, ustosunkowanie wobec zorganizowanych jednostkowych i wspólnotowych form realizowania osobistych odniesień do Boga, sacrum. Religijność należy do właściwości konstytuujących osobę ludzką poprzez jej relacje do wartości transcendentnych [8]. Gordon W. Allport w pracy pt. "Osobowość i religia" wskazuje, że religia każdej jednostki uwarunkowana jest jej potrzebami fizycznymi, jej temperamentem i możliwościami umysłowymi, jej psychogennymi zainteresowaniami wartościami, jej dążeniem do racjonalnego wyjaśnienia a także jej reakcją na otaczającą ją kulturę. Allport opisuje na czym polega religijność wieku młodzieńczego i dojrzałego, czym jest sumienie i zdrowie psychiczne . Podaje istotę zwątpienia i istotę wiary, zakładając, że poczucie dojrzałe jest dobrze zróżnicowane, ma charakter dynamiczny, mimo swojej pochodnej natury, wytwarza konsekwentną moralność, jest wszechstronne, całościowe i heurystyczne [9].

Badacze pokazują, że religijność u pacjentów ze schizofrenią jest związana ze wzrastającą integracją społeczną, malejącym ryzykiem prób samobójczych, malejącym spożyciem substancji psychoaktywnych, zmniejszającym odsetkiem palenia tytoniu, lepszą jakością życia i lepszą prognozą. Odnośnie relacji między religią a adaptacją psychospołeczną wnioski są sprzeczne, z nieznaczną przewagą wpływu religijności na poprawę adaptacji psychospołecznej. Wsparcie religijne i duchowość są kojarzone z przywróceniem społecznym social recovery oraz redukcją szybkości nawrotu. Jednakże u niektórych pacjentów wyższa religijność łączyła się z wyższym ryzykiem prób samobójczych [18,23].

Zbadano związek pomiędzy stopniem aktywności religijnej a zdrowiem psychicznym w podgrupach katolików, protestantów i żydów i stwierdzono, że wyższy poziom zaburzeń występuje u tych osób, które nie praktykują. Metaanaliza z 1983 roku, oparta na 24 badaniach, potwierdziła, że religijność ma umiarkowane, lecz pozytywne związki z psychologicznymi wynikami. Uzdrawiający skutek zaangażowania religijnego dotyczył takich czynników jak wskaźnik samobójstw, uzależnienie od leków i alkoholu, przestępczość, satysfakcja małżeńska, depresja [7]. Religijność człowieka wpływa na jego predyspozycje do zachorowań, w tym także na choroby psychiczne - gdyż osoby ukształtowane religijnie, charakteryzuje dobry ośrodek kontroli zachowań prozdrowotnych. Ponadto osoby takie posiadają oparcie społeczne oraz funkcjonują $\mathrm{w}$ tradycyjnych związkach religijnych. Dzięki temu częściej przeżywają pozytywne emocje i ogółem są zdrowsze [10]. „The Canadian Journal of Psychiatry" z 2009 roku zawiera przegląd badań naukowych $\mathrm{w}$ dziedzinie religii, duchowości i zdrowia psychicznego, dokonany przez Koeninga. Jego systematyczne badania dotyczące zdrowia psychicznego - przeprowadzane w kontekście medycznym, psychiatrycznym i innych, obejmujące wiele grup 
etnicznych (mieszkańców Kaukazu, Afroamerykanów, Hiszpanów i rdzennych Amerykanów) w różnych przedziałach wiekowych (młodzież, wiek średni i ludzie starsi) i w różnych krajach (Stany Zjednoczone, Kanada, Europa i kraje Wschodu) - wykazały, że zaangażowanie religijne jest związane $\mathrm{z}$ lepszym radzeniem sobie ze stresem, mniejszą depresją, mniejszymi skłonnościami samobójczymi, mniejszym lękiem i mniejszą skłonnością do uzależnień od substancji psychoaktywnych [11].

Radzenie sobie religijne

Radzenie sobie religijne to użycie religijnych wierzeń czy zachowań do ułatwienia rozwiązywania problemów celem zapobiegania lub łagodzenia negatywnych konsekwencji emocjonalnych stresujących okoliczności życia. Sprowadza się ono do funkcjonalnie orientowanych ekspresji religijnych i ma charakter wielowymiarowy. Koncepcja religijnego radzenia sobie była udoskonalana i kategoryzowana jako pomocna i pozytywna, szkodliwa i negatywna lub też miała mieszane implikacje. Strategie pozytywnego radzenia sobie religijnego obejmują: oczyszczenie, przebaczenie, ukierunkowanie duchowe, pomoc religijna, poszukiwanie wsparcia od duchowieństwa, wyznaczanie pewnych moralnych granic. Zaś strategie negatywnego religijnego radzenia sobie obejmują niezadowolenie duchowe, pojawianie się demonów, pasywne religijne dostosowywanie się, wypadnięcie $\mathrm{z}$ roli społecznej, pojawianie się sił nadprzyrodzonych, proszenie o bezpośrednie wstawienictwo. Religijne radzenie sobie z mieszanymi implikacjami obejmuje religijne rytuały $\mathrm{w}$ odpowiedzi na kryzys, samokierowanie, dostosowywanie się [3, 21].

Kilka badań oceniło typy religijnego radzenia sobie przez pacjentów $\mathrm{z}$ rozpoznaniem schizofrenii i ich role w radzeniu sobie ze stresującymi sytuacjami. Badania sugerują, że ponad $80 \%$ pacjentów używa religii w radzeniu sobie z ich chorobą. Inni raportują, że u 45\% pacjentów duchowość i religijność była pomocna w życiu z chorobą. Badania, które porównały różne choroby, dowodzą, że pacjenci ze schizofrenią, chorobą afektywną dwubiegunową i zaburzeniem schizoafektywnym używają tego "religijnego radzenia sobie" od wielu lat i postrzegają je jako bardzo pomocne $\mathrm{w}$ walce ze swoją chorobą $\mathrm{w}$ porównaniu np. z pacjentami z zaburzeniem depresyjnym $[17,18]$.

Badania wskazują również, że religijne radzenie sobie wpływa na inne parametry. Okazuje się, że religijne radzenie sobie u pacjentów ze schizofrenią jest skorelowane pozytywnie z psychologicznym i egzystencjalnym dobrostanem. W świetle tych doniesień właściwy religijny rozwój jest skojarzony z lepszym samopoczuciem, lepszym dostosowaniem i mniejszym poczuciem straty związanym $\mathrm{z}$ chorobą psychiczną, gdzie karanie przez Boga i ponowna ocena ludzi przez Boga była wiązana $\mathrm{z}$ gorszym samopoczuciem, dostosowaniem i większym poczuciem straty osobistej [3].
Pozytywne radzenie sobie religijne jest również skojarzone $\mathrm{z}$ wyższą jakością życia $\mathrm{w}$ wymiarze zdrowia psychologicznego. Negatywne radzenie sobie religijne było związane z kolei z niższą jakością życia i więszym poziomem dystresu szacowanym na podst. Depression, Anxiety and Stress Scale. Długotrwałe badania pokazały, że większy wpływ religii i wykorzystanie pozytywnego religijnego radzenia są wyznacznikami wyższej jakości życia i lepszej oceny w skali Clinical Global Impression [17,22].

\section{Duszpasterz czy psychiatra?}

Badania z różnych części świata oceniały modele wyjąśniające choroby utrzymywane przez pacjentów ze schizofrenią i sugerują, że wielu pacjentów ma niemedyczne uzasadnienie dla ich chorób. Większość niemedycznych wyjaśnień poprzez różne analizy sprowadza się do działania sił nadprzyrodzonych. Różnorakie wyjaśnienia obejmują czary czarownic czy dżinów, ezoteryczne, spirytualne czy mistyczne czynniki, problemy rodzinne, wewnętrzne problemy jaźni, trudności ekonomiczne, moce nadprzyrodzone, duchy, diabły, opętanie przez demona, boski gniew, wpływy planetarne, astrologiczne, niezaspokojone dusze, złe uczynki w przeszłości. Badanie z Indii donosi, że około 66$70 \%$ pacjentów ma ostatecznie nie biomedyczne wyjaśnienie, podczas gdy badania z innych części świata podają obecność takich modeli wyjąsniających schizofrenię u około 10\% pacjentów. Międzykulturowe badanie obejmujące wyznawców islamu z Arabii, pacjentów z Jordanii i Niemiec sugeruje, że pacjenci $\mathrm{z}$ Jordanii mają tendencję by wierzyć w ezoteryczne podłoże ich chorób i oni postrzegają chorobę jako groźniejszą. Inne badania sugerują,że ludzie rasy białej podają biologiczne przyczyny o wiele częściej niż mieszkańcy Afryki, Karaibów i Bangladeszu, którzy podają często uwarunkowania społeczne. Badania podają też, że nie medyczne modele wyjaśniające schizofrenię wpływają na wgląd, poszukiwanie pomocy i są związane z gorszym wynikiem leczenia [19].

Badanie z Indii pokazuje, że wielu pacjentów poszukuje pomocy u uzdrowicieli, którzy pozbywają się objawów, co pokazuje, że rodzime motody uzdrawiania są rozważane jako uzupełniające do kierownictwa medycznego w chorobie psychicznej. Ankieta kolejnych pacjentów psychiatrycznych szpitalia w Tamil Nadu, w Południowych Indiach pokazała, że 58\% pacjentów psychotycznych odwiedziło uzdrowiciela religijnego przed konsultacją psychiatryczną. Faktem jest, że badania, sugerują, że poszukiwanie religijnego wsparcia dla chorób psychicznych jest często pierwszym krokiem w zarządzaniu w przypadku chorób psychicznych, jako wynik kulturowego tłumaczenia dla tych chorób. Badania z innych części świata sugerują, że pacjenci ze 
schizofrenią, którzy są uznani jako tacy przez długi czas doświadczają duchowego cierpienia. Badania, które mają swoistą ocenę religijności sugerują, że wyższa religijność jest związana $\mathrm{z}$ niższą preferencją leczenia psychiatrycznego [20].

Rola duszpasterza w leczeniu psychiatrycznym - to czy duszpasterz odpowiednio dojrzale zareaguje na wyzwania oraz $\mathrm{w}$ jakim stopniu będzie umiał odróżnić treści religijne $\mathrm{w}$ chorobie psychicznej od przeżycia religijnego (naturalnego lub patologicznego), może w zasadniczym stopniu zadecydować o dalszych losach pacjenta. W programach edukacji psychiatrycznej pojawia się postulat, by psychiatrzy dysponowali wiedzą z zakresu religioznawstwa oraz zalecenie wrażliwości na sprawy religii i umiejętności rozmowy z pacjentem na temat jego życia duchowego i potrzeb religijnych [7] . Należy łączyć obie dziedziny: religijności i zdrowia, zwłaszcza psychicznego, a co za tym idzie działania psychoterapeuty i księdza, także egzorcysty. Przemawia za tym fakt, że zdrowie psychiczne $\mathrm{w}$ nowoczesnych społeczeństwach w poważnym stopniu się chwieje, twarde wskaźniki, takie, jak: ilość samobójstw, uzależnienia, przestępczość, zaburzenia postresowe, depresyjność narastają w szybkim tempie. Trzydzieści procent pacjentów, zwłaszcza pacjentów psychiatrycznych, przeżywa problemy duchowe. Dotykając tematu zjawisk psychotycznych, przede wszystkim w odniesieniu do subiektywnych doświadczeń religijnych, można zauważyć, że współpraca kapłana i lekarza dla dobra pacjenta staje się czymś oczywistym i wręcz koniecznym [10].

\section{Perspektywa kliniczna}

Jacek Prusak w pracy pt. "Diagnoza różnicująca problemy religijne bądź duchowe - możliwości i ograniczenia kodu V 62.89 w DSM-5" rozpatruje religię i duchowość w kontekście klinicznym - okazuje się, że pomoc psychologiczna jest najbardziej efektywna, gdy jest dostosowana do cech konkretnej osoby, do jej światopoglądu, wartości, duchowości i religijności [12].

V62.89 (Z 65.8): kategorii tej można użyć, gdy przedmiotem zainteresowania klinicznego jest problem religijny lub duchowy. Przykłady obejmują: powodujące stres doświadczenia związane ze zwątpieniem lub utratą wiary, problemy związane z przechodzeniem na nową wiarę lub zwątpieniem $\mathrm{w}$ wartości duchowe, niekoniecznie związane ze zorganizowanym Kościołem lub instytucją religijną [13]. Do czasu pojawienia się DSM-IV, we wcześniejszych jej wersjach oraz w ICD, w doświadczeniach religijnych i duchowych widziano przyczynę psychopatologii pacjenta albo jego symptomatologiczną ekspresję, a religia i duchowość były nadreprezentowane celem zilustrowania psychopatologii. Psychiatrzy i psycholodzy, którzy opracowali zarys kodu
V 62.89 uważają owe doświadczenia anomalne za "duchowe stany kryzysowe" spiritual emergencies czy spiritual crisis, omówione we wprowadzeniu $[12,14]$.

Elementy religijne są zatem wszechobecne w psychopatologii. Treści religijne pojawiają sie w schizofrenii,a opisana przez Kępińskiego tematyka metafizyczna urojeń odnosi się do wątku ontologicznego, eschatologicznego i charyzmatycznego. W depresji endogennej psychiatrzy muszą rozprawić się z urojeniami potępienia, winy i kary, a w nerwicy natręctw zredukować myśli obsesyjne o treści religijnej. Inaczej przedstawiają się zadania psychiatry $\mathrm{w}$ obliczu np. dylematów egzystencjalnych czy kryzysu światopoglądowego, z jakimi boryka się pacjent. W takim przypadku psychiatrę obowiązuje duża ostrożność i wrażliwość na hierarchię wartości pacjenta. Postulowana powszechnie neutralność terapeuty prowadzi nie tylko do uważności i respektowania wymiaru duchowego pacjenta, lecz także może niekiedy nakazywać kontakt $\mathrm{z}$ teologiem o charakterze konsultacji lub wręcz skierowanie danej osoby do duszpasterza [7].

Opis przypadku

Pacjent, 28 lat, kawaler, bezdzietny, mieszkający z ciotką i wujem, rodzice pacjenta zmarli z powodu chorób nowotworowych między 8 a 10 rokiem życia pacjenta, prawdopodobnie oboje chorowali na schizofrenię paranoidalną. Rozstali się oni zaraz po jego urodzeniu, pacjent widział ojca zaledwie kilka razy. Nie ma rodzeństwa, był wychowywany przez dziadków ze strony matki, babcia zmarła 3 lata temu, dziadek pacjenta zmarł gdy pacjent miał 9 lat, do dziś uznaje go za swój największy autorytet. Dziadków ze strony ojca pacjent nie znał.

Systematycznie uczęszczał do szkoły, osiągał średnie wyniki w nauce, nie wagarował, nigdy nie sprawiał problemów wychowawczych. Uzyskał średnie wykształcenie - technik ekonomista, nigdy jednak nie pracował w zawodzie. Podjął studia, których nie ukończył, prawdopodobnie w ten sposób chciał uniknąć służby wojskowej. Od 19 roku życia utrzymywał się z pracy na budowie w Polsce oraz Norwegii. Pracę porzucił w listopadzie 2012 roku, w 26 roku życia, kiedy to poczuł powołanie i postanowił wstąpić do zakonu. Już w dzieciństwie był bardzo religijny, a ową religijność zaszczepiła w nim babcia. Bardzo często modlił się i chodził do kościoła: „Najważniejsza w moim życiu była Maryja, zawsze się do niej wstawiałem o pomoc". W ostatnich latach zaczął częściej chodzić do kościoła, „miałem taką potrzebę”, jeździł $\mathrm{w}$ święte miejsca pomodlić się, był na pielgrzymce $\mathrm{w}$ Fatimie. „Czułem pomoc Boską, czułem się otoczony opieką”. Ponadto pacjent miewał sny, w których widywał różne kościoły i Matkę Boską wzywającą do modlitwy. W odpowiedzi na sny pacjent jeździł po Polsce szukając 
kościołów ze snów, a następnie modlił się w nich za dusze w czyśćcu. Sam określał te sny jako „prorocze”. Wyraźne zwiększenie ilości czasu poświęcanego religii nastąpiło po zakończeniu trwającego 5 lat związku uczuciowego, pacjent planował ślub jednak rodzice wybranki uznali go za nieodpowiedniego kandydata. „Dobrze, że się nie ożeniłem, uniemożliwiłoby mi to rozwój duchowy”.

W zakonie spędził rok, odbywając nowicjat do stycznia 2014 roku, kiedy to ojciec przełożony nakazał mu opuścić zakon oraz zgłosić się do psychologa. Niechętnie opisywał swój stan w tym okresie, przyznał, że występowały u niego myśli, które określał jako „niechciane, dziwne oraz bluźniercze”. Twierdził, iż „nie umiał wtedy odróżnić dobra od zła". Miał wtedy dużo myśli w głowie, przewijających się na przemian z lękiem przed czymś złym, przed szatanem. „Miałem wrażenie, że szatan jest we mnie, zastanawiałem się czy nie jestem opętany”. „Nie słyszałem żadnych głosów, nie widziałem żadnych znaków”. „Szatan chciał zniszczyć moją duszę, to pewnie przez to, że odmawiałem wielokrotnie różaniec, a szatanowi to się nie podobało". Pacjent konsultował się u psychiatry, zalecone leczenie farmakologiczne przerwał po 1,5 tygodnia nie widząc poprawy. W lutym 2014 roku został przywieziony przez zaniepokojoną ciotkę do Szpitala Psychiatrycznego w Radecznicy. Pacjent wyraził zgodę na hospitalizację, na oddziale przebywał 2 miesiące, w tym czasie, jak twierdzi, przyjmował regularnie leki. Po wypisie zaprzestał przyjmowania leków (olanzapina) z powodu, jak podaje, „otumanienia”. Pacjent nie czuł się chory psychicznie, wszystkie swoje trudności tłumaczył karą za popełnione grzechy, twierdził, że nie ma się do kogo modlić, ponieważ Jezus go opuścił. „Wyrzekłem się Boga i teraz nie czuję nic na modlitwie, zrobiłbym wszystko by do mnie wrócił”. „W kościele czułem, iż Bóg do mnie przemawia poprzez osobę kapłana bezpośrednio do mnie, ale osoby na niższym stopniu duchowości tego nie zrozumieją".

Stan pacjenta się nie zmieniał, za namową ciotki, pacjent trafił do Kliniki Psychiatrii w Lublinie. W izbie przyjęć odmawiał odpowiedzi na pytania dotyczące objawów chorobowych, negował choroby somatyczne, nałogi, uczulenia oraz urazy głowy. Był prawidłowo zorientowany auto i allopsychicznie, spokojny oraz dostosowany w zachowaniu. Obserwowano u niego zaburzenia myślenia, wypowiadał treści o cechach urojeń, nie obserwowano cech rozpadu osobowości. Pacjent odmówił leczenia farmakologicznego. Twierdził, iż jego problemy są wyłącznie „sprawą duchową”. Z powodu braku podstaw do wdrożenia leczenia bez zgody, został wypisany z rozpoznaniem F23 (ostre i przemijające zaburzenia psychotyczne) z zaleceniem dalszej obserwacji stanu psychicznego $\mathrm{w}$ kierunku procesu schizofrenicznego. Podczas pobytu na oddziale wykonano pacjentowi badanie elek- troencefalograficzne (wynik w granicach normy), badanie neuropsychologiczne (wynik w normie) oraz badanie osobowości MMPI-I, wynik wskazał na postawę dyssymulacji.

$\mathrm{Z}$ informacji od lekarza leczącego pacjenta w poradni zdrowia psychicznego wynika, iż pacjent po wypisaniu z Kliniki Psychiatrii czuł się dobrze, nie ujawniał objawów psychotycznych, prosił o zaświadczenie o obecnym stanie zdrowia $\mathrm{z}$ intencją ponownego wstąpienia do zakonu. Zaświadczenie otrzymał.

\section{Dyskusja}

Pomimo bliskiego związku pomiędzy religią a schizofrenią ten obszar jest często pomijany w szacowaniu, diagnozowaniu, leczeniu zdrowia psychicznego. Ograniczone dostępne badania pokazują, że religia ma wpływ na ekspresję psychopatologii, zachowań związanych $\mathrm{z}$ poszukiwaniem leczenia podobnie jak z wynikiem leczenia. Dając ważność religii i duchowości dla wielu pacjentów biopsychospołeczny model schizofrenii powinien integrować to samo $\mathrm{w}$ kolejności by osiągnąć podejście całej osoby do leczenia. Wnioski sugerują, że klinicyści są rzadko świadomi ważności religijności pacjentów, nawet gdy duchowość wymaga bycia włączoną w leczenie i opiekę nad pacjentem [15]. Stąd istnieje silna potrzeba uświadamiania klinicystom tego zapotrzebowania pacjentów cierpiących na schizofrenię i powinni oni starać się oceniać religijne i duchowe kwestie ich pacjentów [3]. Religia miesza się czasem z patologią. 0 ile urojenia religijne są częste wśród osób psychotycznych, o tyle zdrowe, zgodne z normą przekonania i praktyki religijne pełnią rolę stabilizującą i mogą zmniejszyć przytłaczającą izolację, strach i utratę kontroli doświadczane przez osoby psychotyczne. Klinicyści powinni znać przekonania oraz aktywności religijne i duchowe swoich pacjentów, doceniać ich wartość, traktować je jako zasób przydatny do zdrowego psychicznego i społecznego funkcjonowania, umieć poznać te sytuacje, w których są one zaburzone. Co więcej istnieje potrzeba dalszego badania tego obszaru, z perspektywy wielokulturowej, w nadziei, że rozumienie relacji pomiędzy religią a różnymi aspektami schizofrenii zaprowadzi do lepszego rozumienia pacjentów przez lekarzy i pozwoli uzyskać lepsze wyniki leczenia.

Przypadek pacjenta ilustruje szczególną trudność diagnostyczną przy ocenie psychopatologii na granicy obszaru kulturowo-religijnego. Wychowanie pacjenta w głębokiej religijności może sugerować badającemu przez pryzmat własnej kultury diagnoście rozpoznanie zaburzenia psychicznego. Autorzy zwracają uwagę na rolę dogłębnego wywiadu i poznania kulturowych i religijnych determinantów zachowań i wypowiedzi pacjenta, czyli tzw. „kulturowe aspekty diagnozy”. Wiele badań wskazuje 
na to, iż pomoc psychiatryczna oraz psychologiczna jest najbardziej skuteczna, gdy uwzględnia światopogląd, wartości, sferę duchowości oraz religijności konkretnej osoby [24,25]. Co więcej, badania wskazują, że pacjenci są mniej skłonni zaufać specjalistom jeśli odczuwają lub podejrzewają negatywne nastawienie wobec ich życia duchowego [26,27] oraz nie ujawniają swoich przeżyć religijnych [24]. Także nasz pacjent widział swój problem nie jako medyczny a duchowy, antycypował niezrozumienie ze strony otoczenia, od początku hospitalizacji mieliśmy do czynienia z brakiem współpracy - pacjent wyrażał przekonanie, że nie może zostać zrozumiany, więc dyssymulował, ograniczał opisy przeżyć religijnych. Utrudniało to znacznie proces diagnostyczny.

W wyżej opisanym przypadku prócz rozpoznania psychozy możemy zauważyć także brak dojrzałości religijnej, dziecięcego przeżywania religii, na co wskazuje chociażby liczenie odprawionych modlitw - pacjent podawał liczbę 5000 różańców - odmówionych w ciągu roku.

Wg statystyk [28] 1/3 studentów posiada problemy religijne bądź duchowe i realnie odbija się to na ich życiu. Wobec powyższego - brak rozeznania w historii religijnoduchowej pacjenta - stanowi poważne zaniedbanie [29]. Badania nad stosunkiem klinicystów wobec takich przeżyć [30,31] wskazują, że przykładają oni przeważnie miarę własnych norm kulturowych do przeżyć pacjentów czyli zdarza się, że oceniaja pacjentów niepsychotycznych jako psychotycznych lub „potencjalnie psychotycznych”, lub przeciwnie interpretują wypowiedzi pacjentów wskazujące na psychotyczność jako potencjalnie niepsychotyczne. Zilustrować to mogą zjawiska anomalne np. relacjonowanie przez pacjenta doznań szczytowych (peak experiences), czyli poczucia zachwytu, uniesienia, olśnienia, a nawet ekstazy występującej przy akcie samorealizacji opisywanych przez Abrahama Maslowa jako znajdujących się w psychologicznej normie i występujących u ludzi zdrowych [32]. Możemy przypuszczać, że przy pobieżnym wywiadzie i badaniu mogą one sugerować specjaliście, że ma do czynienia nie $\mathrm{z}$ innym sposobem przeżywania a przeżyciem psychopatologicznym.

W życiu chorego przeżycia religijne mogą mogą współwystępować z psychopatologią nie wpływając na nią, lub wywiarając wpływ przez jedną z trzech funkcji jakie religia może spełniać. Są nimi:

1. Funkcja pozytywna (salutogenna) - pomaga w budowaniu relacji, w aktywizowaniu pacjenta, jest źródłem wsparcia,

2. Funkcji patoplastycznej - duchowość staje się wyrazem odmiennych form myślenia i zachowania, zapewnia ucieczkę,

3. Funkcji patogennej - duchowość oddziałująca jako stresor na jednostkę pogłębiając słabość lub prowadząc do poważnych form nieprzystosowania. [33]
W omawianym przypadku religia występuje w funkcji patoplastycznej, służy pacjentowi jako ucieczka, sposób radzenia sobie z chorobą, jej wytłumaczenie bądź zaprzeczenie.

Pacjent widział swój problem nie jako medyczny a duchowy, co skutkowało nieufnością wobec personelu $\rightarrow$ (dyssymulacja, poczucie niezrozumienia, brak współpracy) i utrudniało proces diagnostyczny. Dodatkową trudnością przy postawieniu diagnozy jest brak wystandaryzowanych narzędzi pozwalających wyznaczyć granicę głębokiej duchowości i psychopatologii.

\section{References:}

1. S. Grof, C. Grof, Spiritual Emergency. When Personal Transformation Becomes a Crisis, Los Angeles 1989, tylna strona okładki

2. A. Kępiński Schizofrenia PZWL Warszawa 1981 Wyd IV

3. Religion, Spirituality, and Schizophrenia: A Review Sandeep Grover, Triveni Davuluri and Subho Chakrabarti, Indian Journal of Psychological Medicine Apr-Jun 2014, Department of Psychiatry, Post Graduate Institute of Medical Education and Research, Chandigarh, India.

4. D. Janus Psychopatologia a religia Eneteia Warszawa 2004 Wyd pierwsze

5. Greenberg D., Brom D. Nocturnal hallucinations in ultra-orthodox Jewish Israeli men. Psychiatry. 2001;64:81-90

6. Peters E., Day S., McKenna J., Orbach G. Delusional ideation in religious and psychotic populations Br J Clin Psychol. 1999;38:83-96

7. J. Wciórka, S. Pużyński, J. Rybakowski Psychiatria tom3 Wyd II Elsevier Wrocław 2012

8. M.Z. Stepulak Wybrane zagadnienia z psychologii pastoralnej. Wyższe Seminarium Duchowne Siedlce - Opole 2007

9. G. W. Allport Osobowość i religia, Instytut Wydawniczy Pax, Warszawa 1988

10. M. Olajossy Współpraca psychiatry i egzorcysty w: Pokonać szatana egzorcysta czy psychiatra? JUT Wydawnictwo Szczebrzeszyn 2013

11. Koenig HG. Research on religion, spirituality, and mental health: a review. Can. J. Psychiatry 2009; 54: 283-291

12. J. Prusak Diagnoza różnicująca problemy religijne bądź duchowe możliwości i ograniczenia kodu V 62.89 w DSM-5 Psychiatr. Pol. 2016; 50(1): 175-186

13. Diagnostic and statistical manual of mental disorders. Fifth edition. (DSM-5) Washington, DC: American Psychiatric Association; 2013

14. K. Dyga Pomiędzy Psychopatologią a Duchowością Instytut Psychologii Uniwersytetu Jagiellońskiego

15. Lalonde P. Schizophrenies. In: Lalonde PJ, Grundberg F, editors. Psychiatrie bio-psycho-sociale. Montreal: Gaetan Morin; 1999 pp. 242-85.

16. Takeyama M, Asai M, Hashimoto M, Bartels M, Kasper S. Transcultural study of schizophrenic delusions: Tokyo versus Vienna versus Tubingen (Germany) Psychopathology. 1998; 31; 59-68.

17. Tepper L, Rogers SA, Coleman EM, Malony HN. The pravalence of religious coping among persons with persistent mental illness Psychiatr Serv. 2001; 52: 660-665.

18. Huguelet P, Mohr S, Jung V, Gillieron C, Brandt PY, Borras L. Effect of religion on suicide attempts in outpatients with schizophrenia ir schizo-affective disorders compared with inpatients with nonpsychotic disorders. Eur Psychiatry. 2007; 22: 188-194.

19. Napo F., Heinz A., Auckenthaler A. Explanatory models and concepts of West African Malian patients with psychotic symptoms. Eur Psychiatry. 2012; 27 (Suppl 2): S44-9 
20. Johnson S., Sathyaseelan M, Charles H, Jeyaseelan V, Jacob KS. Insight, psychopathology, explanatory models and outcome of schizophrenia in India: A prospective 5-year cohort study. BMC Psychiatry. 2012;12:159

21. Philips R, Stein C. God's will, God's punishment, or God's limitations? Religious coping strategies reported by young adults living with serious mental illness. J Clin Psychol. 2007; 63: 529-40

22. Shah R, Kulhara P, Grover S, Kumar S, Malhorta R, Tyagi S. Contribution of spirituality to quality of life in patients with residual schizophrenia. Psychiatry Res. 2011: 190: 200-205.

23. Borras L., Khazaal Y, Khan R, Mohr S, Kaufmann YA, Zullino D et al. The relationship between addiction and religion and its possible implication for care. Subst Use Misuse. 2010; 45: 2357-410.

24. Pargament KI, Murray-Swank NA, Tarakeshwar N. An empiricallybased rationale for aspirituality-integrated psychotherapy. Ment. Health Relig. Cult. 2005; 8(3): 155-165.

25. Norcross JC. red. Psychotherapy relationships that work. New York: Oxford University Press;

26. Nichole A, Murray-Swank NA, Pargament KI. God, where are you? Evaluating a spiritually-integrated intervention for sexual abuse. Ment. Health Relig. Cult. 2005; 8(3): 191-203.

27. 27.Worthington EL, Kurusu TA, McCullough ME, Sandage SJ. Empirical research on religion and psychotherapeutic process and outcome - A 10-year review and research prospectus. Psychol. Bull. 1996; 119(3): 448-487.

28. Exline JJ, Rose E. Religious and spiritual struggles. W: Paloutzian RF, Park CL. red. Handbook of the psychology of religion and spirituality. New York: Guilford; 2005. s. 315-330.
29. Johnson C, Hayes J. Troubled Spirits: Prevalence and predictors of religious and spiritual concerns among university students and counseling center clients. J. Couns. Psychol. 2003; 50: 409-419

30. Lannert J. Resistance and countertransference issues with spiritual and religious clients. J.Humanist. Psychol. 1991; 31: 68-76.

31. 31.Sanderson S, Vandenberg B, Paese P. Authentic religious experience or insanity? J. Clin. Psychol. 1999; 55: 607-616

32. Sperry L. Spirituality in clinical practice: incorporating the spiritual dimension in psychotherapy and counseling. Philadelphia, PA: Brunner-Routledge; 2001. s. 80-81.

33. Grzymała-Moszczyńska H. Religia a kultura. Wybrane zagadnienia z kulturowej psychologii religii. Kraków: Wydawnictwo Uniwersytetu Jagiellońskiego; 2004. s. 182-198.

\section{Correspondence address}

Ewelina Dziwota

II Klinika Psychiatrii i Rehabilitacji Psychiatrycznej

ul. Głuska 1, 20-439 Lublin

Email: dziwota.e@gmail.com

Otrzymano: 29.02.2016

Zrecenzowano: 30.08.2016

Przyjęto do druku: 11.09.2016 